\title{
Antibacterial Activities of Peptides from the Water-Soluble Extracts of Italian Cheese Varieties
}

\author{
C. G. Rizzello, ${ }^{1}$ I. Losito, ${ }^{2}$ M. Gobbetti, ${ }^{1}$ T. Carbonara, ${ }^{2}$ \\ M. D. De Bari, ${ }^{2}$ and P. G. Zambonin ${ }^{2,3}$ \\ ${ }^{1}$ Dipartimento di Protezione delle Piante e Microbiologia Applicata, \\ 2Dipartimento di Chimica, and \\ ${ }^{3}$ Laboratorio di Spettrometria di Massa per la Proteomica, \\ Università degli Studi di Bari, 70126 Bari, Italy
}

\begin{abstract}
Water-soluble extracts of 9 Italian cheese varieties that differed mainly for type of cheese milk, starter, technology, and time of ripening were fractionated by reversed-phase fast protein liquid chromatography, and the antimicrobial activity of each fraction was first assayed toward Lactobacillus sakei A15 by well-diffusion assay. Active fractions were further analyzed by HPLC coupled to electrospray ionization-ion trap mass spectrometry, and peptide sequences were identified by comparison with a proteomic database. Parmigiano Reggiano, Fossa, and Gorgonzola water-soluble extracts did not show antibacterial peptides. Fractions of Pecorino Romano, Canestrato Pugliese, Crescenza, and Caprino del Piemonte contained a mixture of peptides with a high degree of homology. Pasta filata cheeses (Caciocavallo and Mozzarella) also had antibacterial peptides. Peptides showed high levels of homology with $\mathrm{N}$-terminal, C-terminal, or whole fragments of well known antimicrobial or multifunctional peptides reported in the literature: $\alpha_{\mathrm{S} 1^{-}}$casokinin (e.g., sheep $\alpha_{\mathrm{S} 1^{-}}$ casein (CN) f22-30 of Pecorino Romano and cow $\alpha_{\mathrm{S}^{-}}$ CN f24-33 of Canestrato Pugliese); isracidin (e.g., sheep $\alpha_{\mathrm{S} 1}-\mathrm{CN}$ f10-21 of Pecorino Romano); kappacin and casoplatelin (e.g., cow $\kappa$-CN f106-115 of Canestrato Pugliese and Crescenza); and $\beta$-casomorphin-11 (e.g., goat $\beta$-CN f60-68 of Caprino del Piemonte). As shown by the broth microdilution technique, most of the watersoluble fractions had a large spectrum of inhibition (minimal inhibitory concentration of 20 to $200 \mu \mathrm{g} / \mathrm{mL}$ ) toward gram-positive and gram-negative bacterial species, including potentially pathogenic bacteria of clinical interest. Cheeses manufactured from different types of cheese milk (cow, sheep, and goat) have the potential to generate similar peptides with antimicrobial activity.
\end{abstract} (Key words: antibacterial peptide, Italian cheese)

Received September 22, 2004.

Accepted March 15, 2005.

Corresponding author: M. Gobetti; e-mail: gobbetti@agr.uniba.it.

\begin{abstract}
Abbreviation key: ACE = angiotensin-I converting enzyme, ESI-IT = electrospray ionization-ion trap, MS $=$ mass spectrometry, OPA $=$ o-phthaldialdehyde, RP-FPLC = reversed phase fast protein liquid chromatography, TFA = trifluoroacetic acid.
\end{abstract}

\section{INTRODUCTION}

During the last decade, fundamental studies have opened a new field of research dealing with bioactive or biogenic substances derived from foods. Numerous definitions have been given for bioactive peptides and one of the most appropriate could be the following: components (genuine or generated) of consumption-ready foods which may exert a regulatory activity in the human organism, irrespective of their nutritive functions (Meisel, 2001). Milk proteins are currently the main source of a range of biologically active peptides. Most of these bioactivities in milk are encrypted within the primary structure of milk proteins, requiring proteolysis for their release from precursors. Proteolysis may release the biogenic peptides during gastrointestinal transit or during food processing. For a comprehensive view of the physiological activities of bioactive peptides, see the reviews by Clare and Swaisgood (2000), Meisel (2001), Gobbetti et al. (2002, 2004), Korhonen and Pihlanto (2003), and Floris et al. (2003).

Compared with other bioactivities (e.g., antihypertensive peptides), only a few reports have considered the enzymatic release of antimicrobial peptides in milk and dairy products. Antimicrobial activity can be easily demonstrated by well-diffusion assay (Schillinger and Lucke, 1989), broth microdilution technique (Recio and Visser, 1999; Malkoski et al., 2001; Pellegrini et al., 2001), and during microbial growth in food matrix. This strictly correlates with their potential role in nature. After discovering lactenin in milk treated with rennet (Jones and Simms, 1930), a number of potent antimicrobial peptides have been reported in the literature, namely 1) casecidins, a group of basic, glycosylated, and high molecular mass $(\sim 5 \mathrm{kDa})$ polypeptides, released 
from chymosin-treated CN (Lahov et al., 1971); 2) isracidin, which corresponds to the $\mathrm{N}$-terminal fragment of $\alpha_{\mathrm{s} 1}-\mathrm{CN}$ (Hill et al., 1974); 3) casocidin-I, isolated from acidified milk and corresponding to the fragment f150 188 of $\alpha_{\mathrm{s} 2}$-CN (Zucht et al., 1995); 4) kappacin, corresponding to nonglycosylated, phosphorylated bovine caseinomacropeptide ( $\kappa$-CN f106-169) (Malkoski et al., 2001); and 5) lactoferricin, isolated from a peptic hydrolysate of bovine and human lactoferrins (f17-41 and f147, respectively) (Bellamy et al., 1992; Liepke et al., 2001). More recently, an antimicrobial peptide, corresponding to $\beta$-CN f184-210, was synthesized by hydrolysis of human sodium caseinate with a partially purified proteinase of Lactobacillus helveticus (Minervini et al., 2003). Overall, the activity of antibacterial peptides is defined as a membrane-lytic activity, where they tend to assemble to form channels, with specificity for prokaryotic cell membranes (Floris et al., 2003). Many peptides have $\alpha$-helical structures, are cationic, and amphipathic, but there are also hydrophobic $\alpha$-helical peptides that possess antimicrobial activity (Epand and Vogel, 1999). Compared with antibiotics, antimicrobial peptides have the advantages of being able to kill target cells rapidly and having a broad spectrum of activity, including activity toward some of the most important antibiotic-resistant pathogens in clinics. Because the rate of killing is higher than the rate of bacterial multiplication, the potential to overcome drug resistance is enhanced (Bechinger, 1997).

Overall, the majority of bioactive peptides, including antimicrobial, have been identified in milk, milk hydrolysates, and fermented milks (Meisel, 2001; Gobbetti et al., 2004). Just a few reports have considered the potential of cheeses in containing biogenic substances. Meisel et al. (1997) described the presence of low-molecular-mass angiotensin-I converting enzyme- (ACE) inhibitory peptides in several ripened cheeses. Angiotensin-I converting enzyme inhibitory peptides were also identified in Italian cheeses characterized by short and medium ripening periods (Addeo et al., 1992; Smacchi and Gobbetti, 2000), Manchego Spanish cheese (GomezRuiz et al., 2002), enzyme-modified (Haileselassie et al., 1999), and low-fat (Ryhänen et al., 2001) cheeses. Caseinophosphopeptides were isolated during ripening of cooked curd cheeses such as Comtè (Roudot-Algaron et al., 1994) or Grana Padano (Pellegrino et al., 1997). It was shown that once generated, bioactive peptides might have selective inhibitory activity toward bacterial enzymes responsible for cheese ripening (Gobbetti et al., 2002). Overall, it was demonstrated that biotechnology, type of starters and coagulants, and ripening conditions in cheese making might affect the synthesis of bioactive peptides. To our knowledge, no studies have considered cheeses as a potential source of antimicrobial peptides (Smacchi and Gobbetti, 2000).

This paper describes the antibacterial activities of the water-soluble extracts of 9 Italian cheese varieties that differ for several biotechnological traits. Peptides with high levels of homology with N-terminal, C-terminal, or whole fragments of well known antimicrobial and multifunctional peptides reported in the literature were isolated and identified from water-soluble extracts.

\section{MATERIALS AND METHODS}

\section{Cheeses}

Nine Italian cheese varieties were considered in this study: Parmigiano Reggiano, Pecorino Romano, Fossa, Canestrato Pugliese, Caciocavallo, Gorgonzola, Crescenza, Mozzarella, and Caprino del Piemonte. As shown in Table 1, these varieties differ mainly for type of cheese milk, starter, technology, and time of ripening. Based on the moisture content, cheeses are usually classified as extrahard (Parmigiano Reggiano, Pecorino Romano, Fossa, and Canestrato Pugliese), hard (Caciocavallo), or fresh (Gorgonzola, Crescenza, Mozzarella, and Caprino del Piemonte) varieties. Caciocavallo and Mozzarella are also included in the "pasta filata" cheeses, and Gorgonzola belongs to the "blue cheese" variety. Cheeses were supplied in triplicate by official cheese makers and were stored at $4^{\circ} \mathrm{C}$ for a few hours before preparing the water-soluble extracts.

The $\mathrm{pH}$ of cheeses was determined as described by the International Dairy Federation (1989). Total nitrogen $(\mathrm{N})$ and $\mathrm{pH}$ 4.6-soluble $\mathrm{N}$ were determined by the microKjeldahl method.

\section{Water-Soluble Extracts}

Water-soluble extracts of cheeses were prepared according to the method of Kuchroo and Fox (1982) with some modifications. Thirty grams of cheese was suspended in $90 \mathrm{~mL}$ of $50 \mathrm{mM}$ phosphate buffer $\mathrm{pH} 7.0$ and treated for $10 \mathrm{~min}$ with a Stomacher (PBI International, Milano, Italy). The suspension was kept at $40^{\circ} \mathrm{C}$ for 1 $h$ under gentle stirring (150 rpm) and centrifuged at $3000 \times g$ for $30 \mathrm{~min}$ at $4^{\circ} \mathrm{C}$. The supernatant was filtered through Whatman no. 2 paper, and the $\mathrm{pH}$ of the extract was adjusted to 4.6 using $1 \mathrm{~N} \mathrm{HCl}$. The precipitated casein was recovered by centrifugation at $10,000 \times g$ for $10 \mathrm{~min}$. Finally, the supernatant was filtered through a Millex-HA $0.22-\mu \mathrm{m}$ pore size filter (Millipore Co., Bedford, MA). 


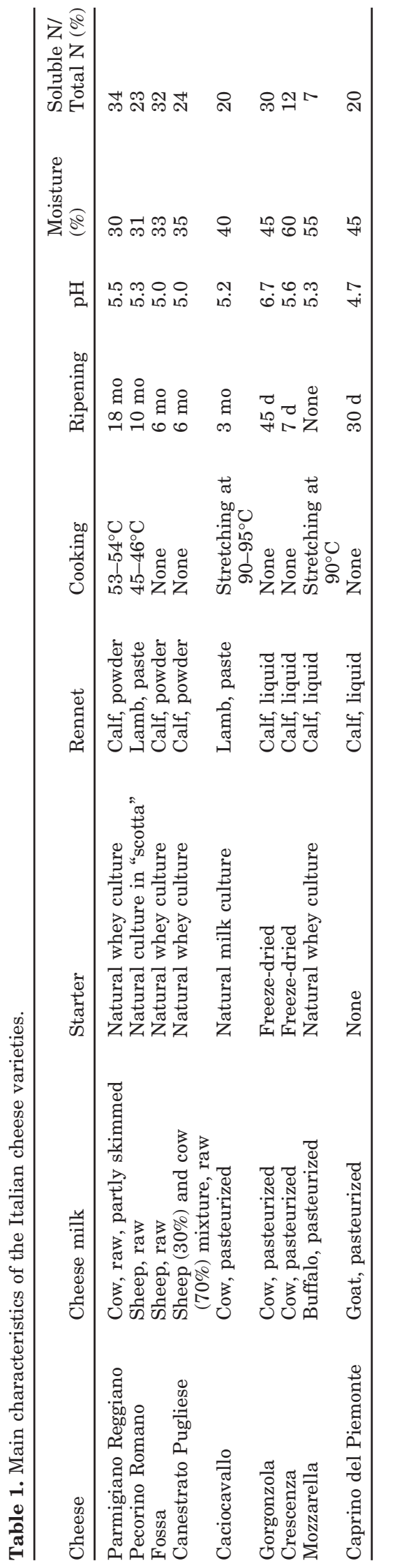

\section{Isolation of Peptides from Water-Soluble Extracts}

Peptides were separated from water-soluble extracts by reversed-phase fast protein liquid chromatography (RP-FPLC), using a Resource RPC column and ÄKTA FPLC equipment with a UV detector operating at 214 nm (Amersham Biosciences, Uppsala, Sweden). This method is largely used for isolation of biologically active peptides from complex food matrices (e.g., Liepke et al., 2001; Pellegrini et al., 2001; Gomez-Ruiz et al., 2002). For each cheese, a volume of water-soluble extract containing $\sim 30 \mathrm{mg}$ of peptides, as determined by the ophthaldialdehyde (OPA) method (Church et al., 1983), was separated. Aliquots $(\sim 2 \mathrm{~mL})$ of the water-soluble extracts were added to $0.05 \%$ ( $\mathrm{vol} / \mathrm{vol}$ ) trifluoroacetic acid (TFA), and centrifuged at $10,000 \times g$ for $10 \mathrm{~min}$. The supernatant was filtered through a Millex-HA 0.22$\mu \mathrm{m}$ pore size filter (Millipore Co.) and loaded onto the column. Gradient elution was performed at a flow rate of $1 \mathrm{~mL} / \mathrm{min}$ using a mobile phase composed of water and acetonitrile containing $0.05 \%$ TFA. The $\mathrm{CH}_{3} \mathrm{CN}$ content was increased linearly from 5 to $46 \%$ between 16 and $62 \mathrm{~min}$, and from 46 to $100 \%$ between 62 and $72 \mathrm{~min}$. Solvents were removed from the collected 2$\mathrm{mL}$ fractions by freeze-drying. The fractions were redissolved in $600 \mu \mathrm{L}$ of water and assayed for antibacterial activity. The $\mathrm{pH}$ of the fractions ranged from 5.8 to 6.2.

The peptide concentration in the water-soluble extracts and related fractions was determined by the OPA method (Church et al., 1983). The reaction mixture contained $500 \mu \mathrm{L}$ of OPA reagent and $12.5 \mu \mathrm{L}$ of peptide sample. Absorbance at $340 \mathrm{~nm}$ was determined. The peptide concentration was calculated from a standard curve prepared using tryptone $(0.25$ to $1.5 \mathrm{mg} / \mathrm{mL})$ as reference. The use of peptone as standard gave similar results.

\section{Antibacterial Activity}

Preliminarily, a well-diffusion assay was used to detect the antibacterial activity of the water-soluble extracts and peptide fractions (Schillinger and Lucke, 1989). Escherichia coli $\mathrm{K} 12$ and Yersinia enterocolitica $\mathrm{X} 8$ of human origin, Bacillus megaterium $\mathrm{F} 6$ from fresh vegetables, and Listeria innocua DSM 20649 from fresh meat on LB agar medium, Staphylococcus aureus ATCC25923 of human origin and Lactococcus lactis spp. cremoris WG2 from cheeses on M17 agar medium, Salmonella spp. from fresh meat on Muller and Kauffman agar medium, and Lactobacillus sakei A15 from fresh meat and Lactobacillus helveticus PR4 from cheeses on MRS agar medium were used to characterize antibacterial activity. All cultures belong to the Culture Collection of the Department of Plant Protection and Applied Microbiology, University of Bari, Italy. Lactobacillus 
sakei A15 was used as indicator strain for the preliminary screening of the antibacterial activity. As shown by the characterization of antibacterial activity, the sensitivity of this strain was similar to that of $E$. coli $\mathrm{K} 12$. The assays were carried out in the different media overlaid with $15 \mathrm{~mL}$ of agar- $\mathrm{H}_{2} \mathrm{O}(2 \%$, wt/vol $)$ and $5 \mathrm{~mL}$ of different soft agar media that contained $10^{4} \mathrm{cfu} / \mathrm{mL}$ of an overnight culture of the indicator strain. Wells, $1.5 \mathrm{~cm}$ in diameter, were cut into these agar plates, and $200 \mu \mathrm{L}$ of the water-soluble extract or peptide fraction (diluted 1:1 with distilled sterile water) were placed into each well. Plates were stored at $4^{\circ} \mathrm{C}$ for $4 \mathrm{~h}$ to permit radial diffusion of the peptide, incubated at 30 or $37^{\circ} \mathrm{C}$ for $24 \mathrm{~h}$, and subsequently examined for zones of inhibition. Peptide fractions that showed activity on indicator strain were further characterized for their activity spectrum.

After further purification by RP-FPLC, the antibacterial activity of water-soluble fractions containing peptides was further characterized by broth microdilution technique (Recio and Visser, 1999; Malkoski et al., 2001; Pellegrini et al., 2001). Logarithmic phase cells $\left(\sim 10^{8} \mathrm{cfu} / \mathrm{mL}\right)$ of $E$. coli K12, Y. enterocolitica X8, B. megaterium F6, and L. innocua DSM 20649 cultivated on LB broth at $37^{\circ} \mathrm{C}$, Staph. aureus ATCC25923 and L. lactis spp. cremoris WG2 on M17 broth at 37 and $30^{\circ} \mathrm{C}$, respectively, Salmonella spp. on Muller and Kauffman broth at $37^{\circ} \mathrm{C}$, and L. sakei $\mathrm{A} 15$ and $L$. helveticus PR4 on MRS broth at $37^{\circ} \mathrm{C}$ were harvested by centrifugation at $8000 \times g$ for $10 \mathrm{~min}$, washed twice with $10 \mathrm{mM}$ phosphate buffer, $\mathrm{pH} 7.0$, and adjusted to $10^{4} \mathrm{cfu} / \mathrm{mL}$. The antibacterial assays were carried out in sterile 96-well microtiter plates (Greiner Labortechnik, Frickenhasuen, Germany). Fifty microliters of each cell suspension was mixed with $50 \mu \mathrm{L}$ of each peptide fraction, and $100 \mu \mathrm{L}$ of each specific culture broth was added. Peptide fractions were tested at concentrations ranging from 5 to $600 \mu \mathrm{g} / \mathrm{mL}$. Control wells contained all the components except peptide fraction, which was replaced with distilled water (positive control) or with chloramphenicol at a final concentration of $100 \mu \mathrm{g} / \mathrm{mL}$ (negative control). Microplates were incubated at 30 or $37^{\circ} \mathrm{C}$ depending on the indicator strain, and growth was monitored over $24 \mathrm{~h}$ by measuring the optical density of the culture at $620 \mathrm{~nm}$ using a microplate reader (Dynatech Laboratories, West Sussex, UK). The MIC was determined as the lowest concentration of peptide fraction required to completely inhibit the growth of the bacterium. When growth was inhibited by peptide fractions, cells of indicator strains were recovered from microplates, washed twice with $10 \mathrm{~m} M$ phosphate buffer, $\mathrm{pH} 7.0$, inoculated in fresh culture broth, and incubated at 30 or $37^{\circ} \mathrm{C}$ for $24 \mathrm{~h}$ to allow the recovery of growth. Inhibition as determined by measurement of the optical density at $620 \mathrm{~nm}$ was confirmed by plating in appropriate agar culture media. The assays were carried out in triplicate.

\section{Purification and Sequencing of Antibacterial Peptides}

The fractions of the water-soluble extracts with the highest antimicrobial activity were underwent RPFPLC a second time on the Resource reverse-phase column under the conditions described previously. The centers of the inhibitory peaks were collected, freezedried, and used for mass spectrometry analysis.

The latter was accomplished by HPLC coupled to electrospray ionization-ion trap (ESI-IT) mass spectrometry (MS). A Waters (Milford, MA) 600-MS multisolvent delivery system connected to a Supelcosil LC-18-DB column $(250 \times 2.1 \mathrm{~mm}$ i.d., Supelco, Bellefonte, PA) was used for HPLC separations. The chromatographic column was coupled, through an ESI interface, to an LCQ (Finnigan MAT, San Jose, CA) ion trap mass spectrometer. The divert/inject valve embedded in the spectrometer was used as loop injector (loop volume: $40 \mu \mathrm{L}$ ).

Chromatographic separations were performed using a 2-solvent gradient elution: solvent A was $0.1 \% \mathrm{TFA}$ ( $\mathrm{vol} / \mathrm{vol}$ ) in water and solvent B was $0.1 \% \mathrm{TFA}$ (vol/vol) in acetonitrile. A linear gradient from 0 to $70 \%$ solvent B over 40 min was always adopted. The flow rate was $0.16 \mathrm{~mL} / \mathrm{min}$ and the temperature was ambient.

The ESI spectrometer, fully controlled by the Xcalibur software, was operated in positive ion mode. The electrospray conditions were as follows: spray voltage: $4.5 \mathrm{kV}$; sheath gas (nitrogen) flow rate: $1.05 \mathrm{~L} / \mathrm{min}$; capillary voltage: $14.0 \mathrm{~V}$; heated capillary temperature: $190^{\circ} \mathrm{C}$; tube lens offset voltage: $35.0 \mathrm{~V}$; octapole 1 offset: $-3.0 \mathrm{~V}$; octapole 2 offset: $-5.0 \mathrm{~V}$; lens voltage: $-16.0 \mathrm{~V}$; octapole RF amplitude: $400.0 \mathrm{~V}$; trap DC offset: $-10.0 \mathrm{~V}$.

Different MS acquisition modes were adopted for each sample. Mass spectrometry chromatograms were obtained first in full scan mode, recording mass spectra in the range 50 to $2000 \mathrm{Th}$, then in MS/MS full scan mode. In the latter stage, the main ions observed in the full scan spectra (parent ions) were isolated within the ion trap and fragmented with a fixed collisional energy ( $30 \%$ of the maximum value available). Full scan spectra of the fragments (daughter ions) were recorded afterwards.

The $m / z$ ratio values relevant to each parent ion selected from the MS full scan spectra and to its daughter ions, observed in the MS/MS full scan spectra, were introduced into the NCBInr database by means of Protein Prospector MS-Tag software (http://prospector.uc- 
sf.edu/ucsfhtml4.0/mstagfd.htm). Details about the searching procedure will be given in the Results section.

\section{RESULTS}

\section{Production of Cheese Water-Soluble Extracts}

The 9 Italian cheeses (Table 1) were chosen because they corresponded to varieties manufactured by: 1) cow (Parmigiano Reggiano, Caciocavallo, Gorgonzola, and Crescenza), sheep (Pecorino Romano and Fossa), sheep and cow in mixture (Canestrato Pugliese), buffalo (Mozzarella), or goat (Caprino del Piemonte) milk; 2) freezedried (Gorgonzola and Crescenza) or natural thermophilic (all the other cheeses, except for Caprino del Piemonte) starters; (3) lamb paste (Pecorino Romano and Caciocavallo) or calf rennet (all other cheeses); (4) cooking (Parmigiano Reggiano and Pecorino Romano) or stretching (Caciocavallo and Mozzarella) of curd; and (5) very long (Parmigiano Reggiano and Pecorino Romano), long (Fossa and Canestrato Pugliese), medium (Caciocavallo), and absent to short (Mozzarella, Crescenza, Caprino del Piemonte, and Gorgonzola) ripening time. These features were considered representative of most of the cheese making options that may influence directly or indirectly the synthesis of biologically active peptides.

The peptide concentration of the water-soluble extracts of the 9 Italian cheese varieties ranged from approximately 1.0 (Mozzarella) to approximately $60 \mathrm{mg} /$ $\mathrm{mL}$ (Parmigiano Reggiano) (data not shown), which agreed with the values of soluble N/total N (Table 1). The concentration of peptides increased with the time of cheese ripening (Gobbetti et al., 2004). Before fractionation by RP-FPLC, only the water-soluble extracts of Crescenza and Caprino del Piemonte cheeses showed antibacterial activity against $L$. sakei $\mathrm{A} 15, E$. coli $\mathrm{K} 12$, B. megaterium F6, and L. innocua DSM 20649 (data not shown). For each cheese, a volume of water-soluble extract containing about $30 \mathrm{mg}$ of peptides was then fractionated by RP-FPLC. As shown in Figure 1, Parmigiano Reggiano (A), Pecorino Romano (B), Fossa (C), and Caciocavallo (E) cheeses had a similar peptide profiles, that is, they were rich in peptides in the hydrophilic zone of the acetonitrile gradient. Although with marked differences, Canestrato Pugliese, Crescenza, Mozzarella, and Caprino del Piemonte cheeses (Figure $1 \mathrm{D}, \mathrm{G}, \mathrm{H}$, and I) showed more complex profiles that were always characterized by an abundance of peptides in the hydrophobic zone of the acetonitrile gradient. The peptide profile of Gorgonzola cheese (F) differed from the others.

The cheese water-soluble extracts of the 3 batches were characterized by almost similar peptide profiles.

\section{Isolation of Antimicrobial Peptides}

Thirty-six fractions of each cheese water-soluble extract were collected by RP-FPLC. Theoretically, TFA used in the mobile phase of the RP-FPLC may form salts with protonated peptides (usually in an equimolecular ratio) contained in the water-soluble extract fractions, persist in the freeze-dried preparations, and generate the anionic form when added to the bacterial culture media ( $\mathrm{pH}$ above 6.0). Three main findings excluded the interference of TFA under the conditions of the antibacterial assays. First, TFA at a concentration ranging from 110 to $200 \mu M$ (approximately equimolecular to the average concentration of the peptides identified in the antibacterial fractions, see below) was directly added to the culture broths as a substitute for antibacterial fractions (broth microdilution technique) and the growth of indicator strains was not affected. Second, the peptide concentration of the 36 fractions of each water-soluble extract ranged from 0.3 to $13.2 \mathrm{mg} /$ $\mathrm{mL}$, and antibacterial activity was found in 9 fractions only that had peptide concentrations lower than $3 \mathrm{mg} /$ $\mathrm{mL}$. Third, the water-soluble extracts of Crescenza and Caprino del Piemonte cheeses showed antibacterial activity before fractionation by RP-FPLC (see above).

Preliminarily, the antimicrobial activity of each fraction was assayed by a well-diffusion assay (Schillinger and Lucke, 1989) using L. sakei A15 as an indicator strain. Parmigiano Reggiano, Fossa, and Gorgonzola water-soluble extracts did not contain fractions that showed antibacterial activity under our assay conditions (Figure 1). The other cheese water-soluble extracts showed inhibitory fractions located in the same zone of the acetonitrile gradient: fraction 21 (retention time 40 to $42 \mathrm{~min}$ ) for Pecorino Romano; 21, 22, and 23 (retention times 40 to 42,42 to 44 , and 44 to $46 \mathrm{~min}$, respectively) for Canestrato Pugliese, 22 and 24 (retention times 42 to 44 and 46 to $48 \mathrm{~min}$, respectively) for Crescenza, and 19 (retention time 36 to $38 \mathrm{~min}$ ) for Caprino del Piemonte. Fraction 3 (retention time 4 to $6 \mathrm{~min}$ ) was found to be inhibitory for both Caciocavallo and Mozzarella cheeses. The antibacterial activity of the above fractions always produced inhibitory halos of 3 to $6 \mathrm{~mm}$ toward the indicator strain L. sakei A15.

All the antibacterial fractions of each water-soluble extract were subsequently purified by RP-FPLC.

\section{Identification of Antibacterial Peptides}

As cited in the Materials and Methods section, each purified active fraction was further analyzed by HPLCESI-MS. In particular, the first chromatographic run for each sample was performed using an MS full-scan acquisition mode. 

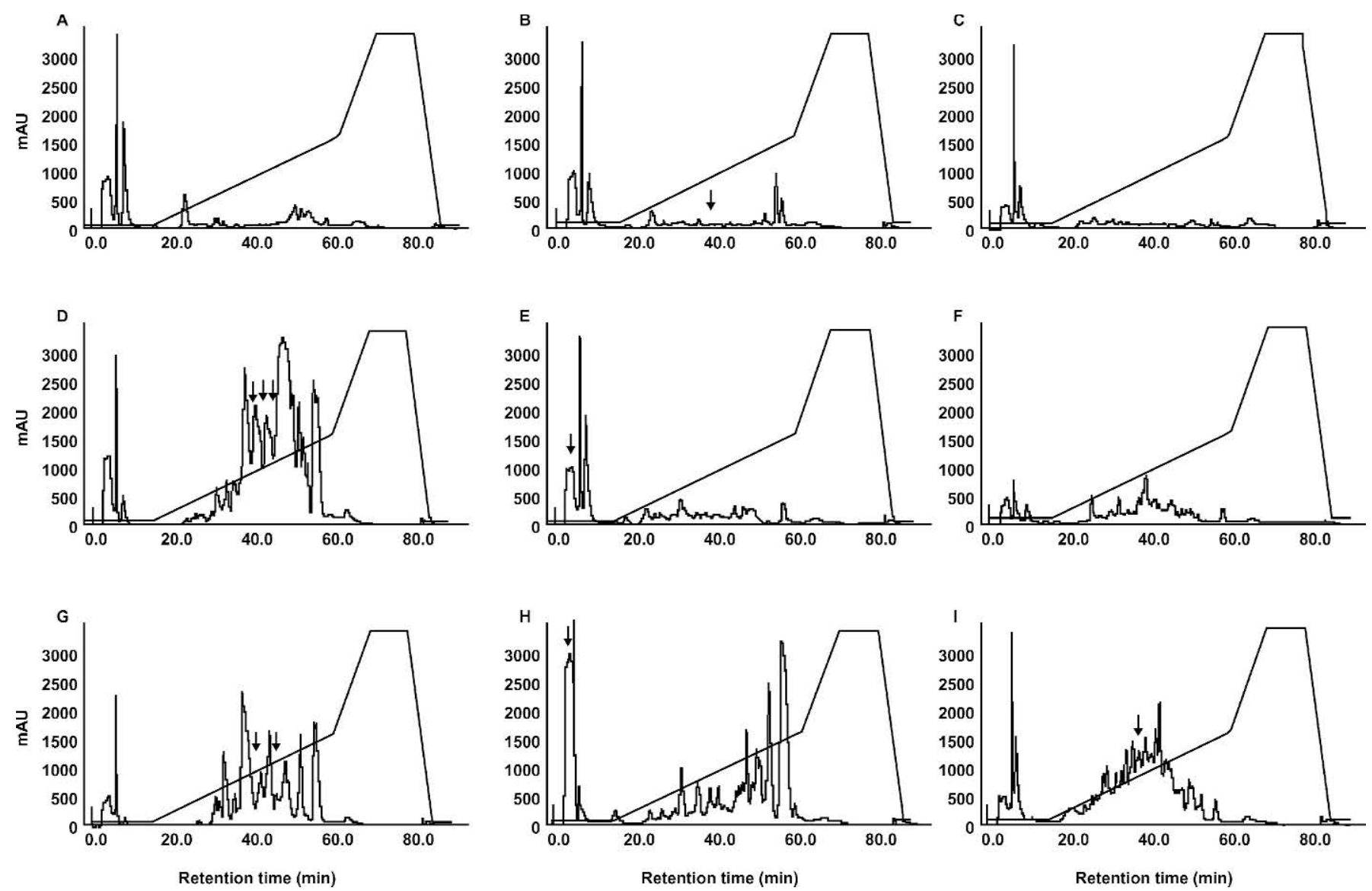

Figure 1. Reversed phase-fast protein liquid chromatograms of the water-soluble extracts from cheeses. A. Parmigiano Reggiano; B. Pecorino Romano; C. Fossa; D. Canestrato Pugliese; E. Caciocavallo; F. Gorgonzola; G. Crescenza; H. Mozzarella; I. Caprino del Piemonte. Arrows indicate peptide fractions with antibacterial activity.

As an example, the MS full-scan chromatogram relevant to fraction 24 of Crescenza cheese is shown in Figure 2A. The chromatogram is reported in the base peak mode, i.e., as a plot of the relative abundance for the highest peak in each MS spectrum recorded during the chromatographic run. Due to the matrix complexity, several species can be identified and in many cases, adjacent peaks are not fully resolved. Nevertheless, it is possible to display all coeluting species separately by filtering the signal on particular $m / z$ values. Figure 2B shows 3 virtual chromatograms obtained by filtering a posteriori the corresponding full MS chromatogram on the following $\mathrm{m} / z$ ratios: 1882.1, 1052.5, 292.0, corresponding to 3 species all eluting at $38.49 \mathrm{~min}$, as confirmed by the full ESI-MS spectrum recorded at this retention time (not shown). It is apparent that mass spectrometry allows one to distinguish species not resolved in the time domain of the chromatographic separation.

All the species identified in the preliminary analysis were isolated within the ion trap of the mass spectrome- ter and fragmented during a further chromatographic run. An MS/MS spectrum was then collected for each of them. The MS/MS spectrum of the $m / z 1052.5$ ion, selected from the MS full-scan chromatogram of active fraction 24 of Crescenza cheese is shown in Figure 3. All the $m / z$ ratios for which a signal was observed in these spectra were inserted, together with the $m / z$ ratio of the parent ion, in the NCBInr database. Before searching, the following parameters were specified: species (Bos taurus, Ovis aries, Capra hircus, according to the species whose milk was used to produce the cheese), $\mathrm{m} / z$ ratio tolerance for parent and daughter ions recognition (0.2 Da), and, finally, the instrumentation used for MS analysis (ion trap).

As expected, many of the selected MS/MS spectra could not be attributed to any peptide sequence within the proteins classified in the database. Due to the complexity of the food matrix, it is reasonable to hypothesize that they are related to nonpeptidic water-soluble components (e.g., organic acids, vitamins) present in the fractions of the cheese extracts. On the other hand, 

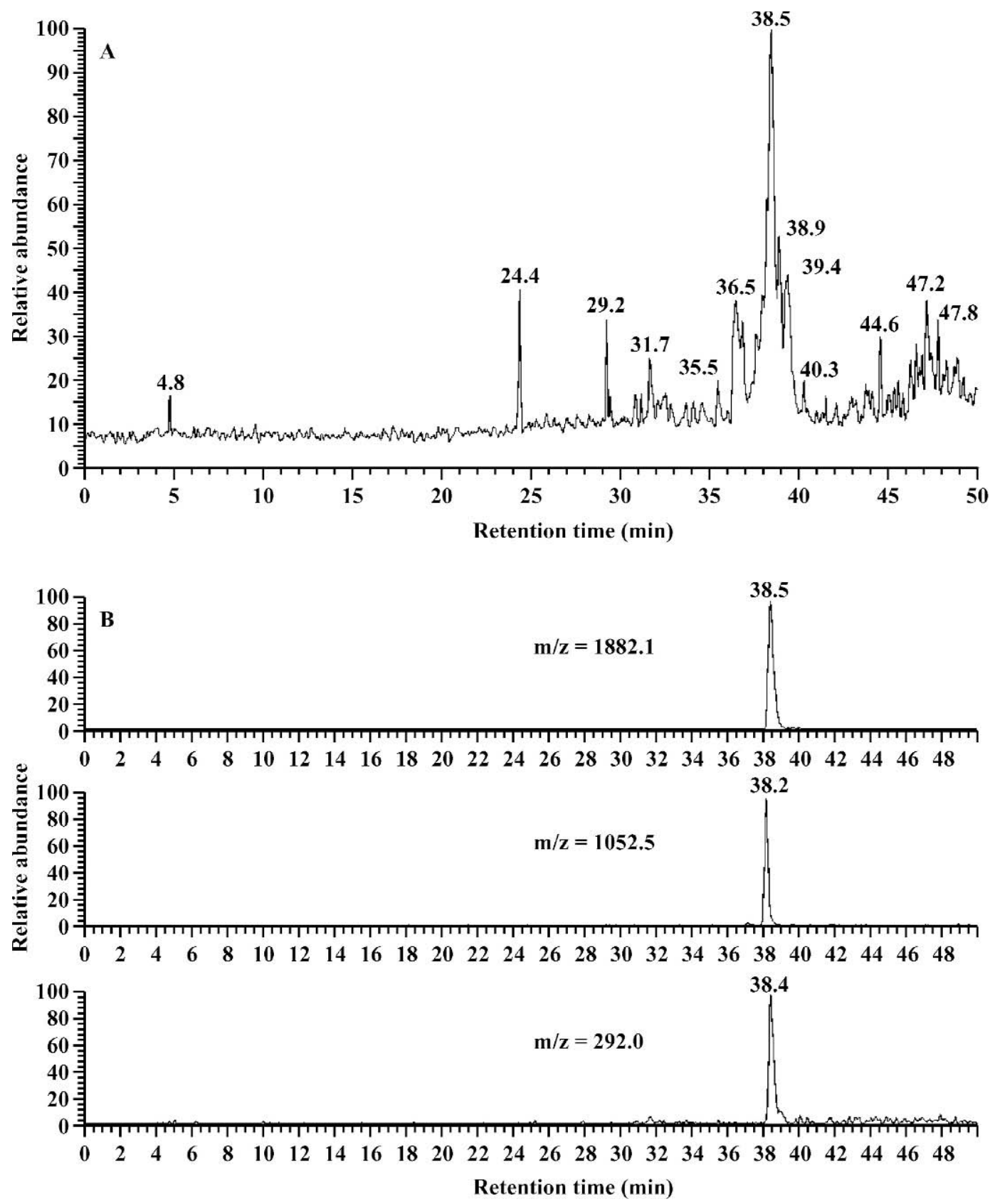

Figure 2. A) HPLC-electrospray-mass spectrometry (MS) full scan chromatogram relevant to active fraction 24 obtained from Crescenza cheese. Relative abundance refers to the intensity of the most abundant peak (base peak) observed in each MS spectrum recorded during the HPLC separation. B) Virtual electrospray ionization-mass spectrometry chromatograms obtained by filtering electronically the real chromatogram (A) on 3 specific $\mathrm{m} / \mathrm{z}$ ratios, corresponding to coeluting peaks.

some spectra could be attributed to one or, more frequently, to several peptide sequences; in these cases, a careful check of the correspondence between experimental and reported data was performed. In particular, the correlation between the $m / z$ ratios set proposed by the database for each candidate amino acid sequence and the $m / z$ values found for the most abundant ions in the corresponding MS/MS spectrum was considered.
As an example, 6 amino acid sequences were proposed for the ion at $\mathrm{m} / z 1052.5$ in the active fraction 24 of Crescenza cheese extract: FVAPFPEVF, DFMDLLVAE, LYKGADSAVE, TADMTNTADL, DMVIEAVFE, FFVAPFPEV, for which the matching between experimental and theoretical $\mathrm{m} / \mathrm{z}$ ratios (within the $0.2 \mathrm{Da}$ tolerance) occurred for the same number of ions. Among these sequences, only FVAPF- 


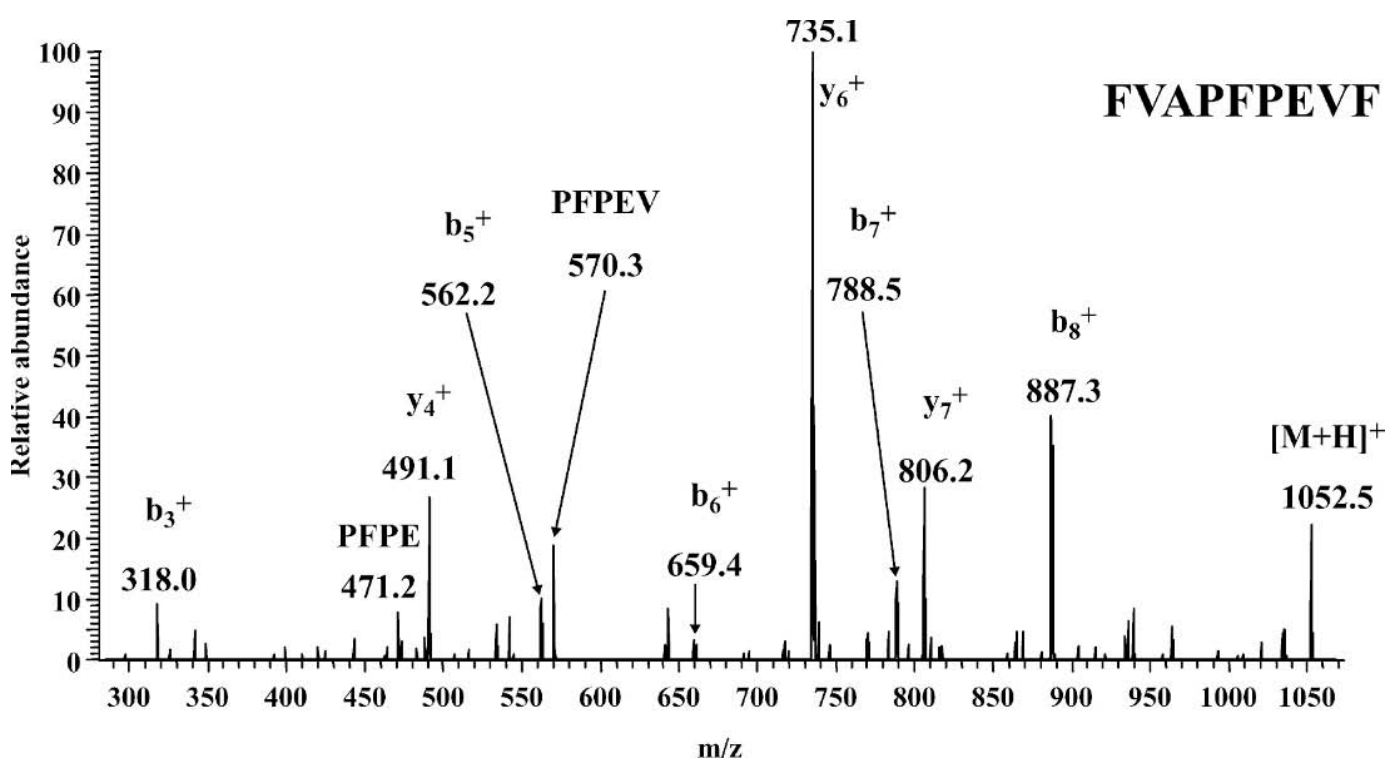

Figure 3. An MS/MS spectrum relevant to the species at m/z 1052.5 observed in the chromatogram of Figure $2 \mathrm{~A}$. The assignments of the different peaks are shown for the corresponding peptide sequence (FVAPFPEVF).

PEVF, belonging to bovine $\alpha_{\mathrm{S} 1}-\mathrm{CN}$, was able to explain the most abundant ions found in the MS/MS spectrum, as shown in Figure 3, in which the conventional nomenclature for peptide fragments has been adopted, the only exceptions being internal fragments (PFPE and PFPEV).

The methodological approach described so far has been used throughout this study and the identified sequences are summarized in Table 2.

It is apparent that almost all the selected fractions contained a mixture of peptides. Fraction 21 from Pecorino Romano cheese had the sequences $\alpha_{\mathrm{S1}}-\mathrm{CN}$ f10-21, $\alpha_{\mathrm{S} 1}-\mathrm{CN}$ f22-30, $\alpha_{\mathrm{S} 1}-\mathrm{CN}$ f24-31, and $\beta$-CN f155-163 from sheep caseins. Due to the very close positions within the acetonitrile gradient, fractions 21, 22, and 23 of Canestrato Pugliese cheese showed an expected overlap of most of the sequences identified. Indeed, cow $\kappa$-CN f106-115 and $\kappa$-CN f161-169, and sheep $\beta$-CN f183188 were identified in all 3 fractions. Fractions 22 and 23 also contained cow $\alpha_{\mathrm{S} 1}-\mathrm{CN}$ f24-33, and fraction 23 had the sequence cow $\alpha_{\mathrm{S1}}-\mathrm{CN}$ f33-43. The sequences of cow $\alpha_{\mathrm{S} 1}-\mathrm{CN}$ f1-7 and $\alpha_{\mathrm{S} 1}-\mathrm{CN}$ f10-14 were identified in fraction 3 of Caciocavallo cheese. Fraction 3 from Mozzarella, the other pasta filata cheese, showed an antibacterial activity but, in this case, the HPLC-ESIMS analysis did not permit peptide identification. Fractions 22 and 24 of Crescenza cheese had the sequence cow $\alpha_{\mathrm{S} 1}$-CN f24-33 in common, whereas $\kappa$-CN f106$115, \beta-\mathrm{CN}$ f183-199, and $\beta$-CN f175-182 were identified in fraction 22 only. The mixture of peptides identified in fraction 19 of Caprino del Piemonte cheese corres- ponded to goat $\beta$-CN f60-68, $\beta$-CN f183-187, $\beta$-CN f155-162, and $\alpha_{\mathrm{S} 1-\mathrm{CN}}$ f24-30.

\section{Characterization of Antibacterial Activity}

After the preliminary screening by well-diffusion assay, the antibacterial activity of the further purified water-soluble fractions was characterized by broth microdilution technique (Recio and Visser, 1999; Malkoski et al., 2001; Pellegrini et al., 2001). Except for fraction 3 of Caciocavallo cheese, the fractions showed a rather large spectrum of inhibition of gram-positive and gramnegative species with MIC ranging from 25 to $200 \mu \mathrm{g} /$ $\mathrm{mL}$ (Table 3). Inhibition was also found against potentially pathogenic bacteria of clinical interest such as $E$. coli $\mathrm{K} 12$, Y. enterocolitica X8, B. megaterium F6, $L$. innocua DSM 20649, Staph. aureus ATCC25923, and Salmonella spp. For instance, fractions 21 of Pecorino Romano and 19 of Caprino del Piemonte inhibited the above potentially pathogenic bacteria with MIC that varied from 25 to $70 \mu \mathrm{g} / \mathrm{mL}$. Fraction 23 of Canestrato Pugliese cheese had a similar inhibitory profile and MIC to fraction 22, whereas fraction 21 did not inhibit L. helveticus PR4, Staph. aureus ATCC25923, or Salmonella spp. Compared with fraction 22, fraction 23 of Crescenza cheese did not inhibit $L$. helveticus PR4, $L$. innocua DSM 20649, or Staph. aureus ATCC25923 (data not shown).

After assay, cells of the inhibited indicator strain were recovered from microplates, washed twice with $10 \mathrm{~m} M$ phosphate buffer, $\mathrm{pH}$ 7.0, inoculated in fresh 
Table 2. Sequences and corresponding CN fragments of peptides contained in antibacterial crude fractions from water-soluble extracts of several Italian cheese varieties. In the last column the ions assigned for each peptide (indicated by the conventional nomenclature) are reported.

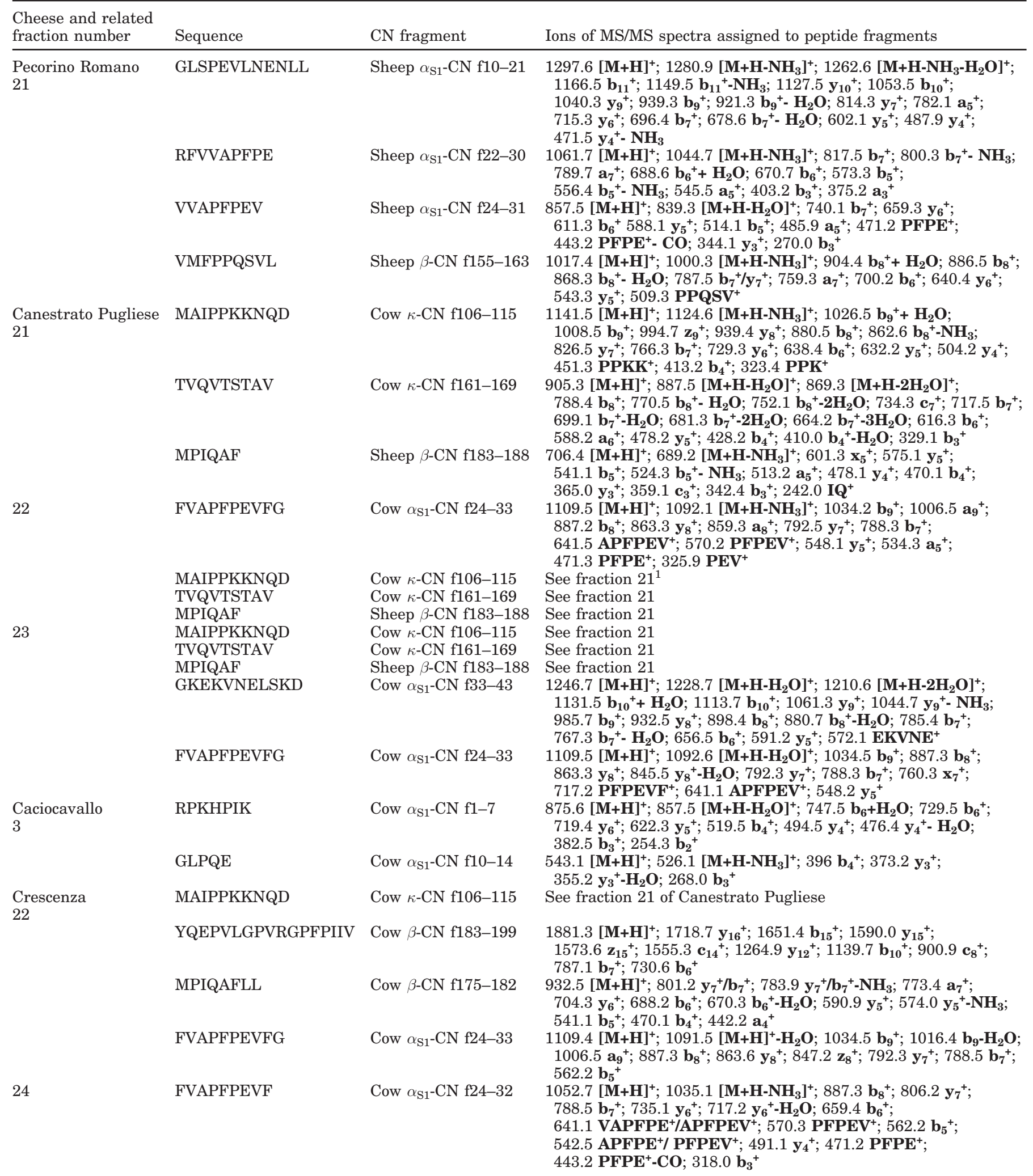


Table 2 (Continued). Sequences and corresponding CN fragments of peptides contained in antibacterial crude fractions from water-soluble extracts of several Italian cheese varieties. In the last column the ions assigned for each peptide (indicated by the conventional nomenclature) are reported.

\begin{tabular}{|c|c|c|c|}
\hline $\begin{array}{l}\text { Cheese and related } \\
\text { fraction number }\end{array}$ & Sequence & CN fragment & Ions of MS/MS spectra assigned to peptide fragments \\
\hline \multirow[t]{4}{*}{$\begin{array}{l}\text { Caprino del } \\
\text { Piemonte } \\
19\end{array}$} & YPFTGPIPN & Goat $\beta$-CN f60-68 & $\begin{array}{l}1005.5[\mathbf{M}+\mathbf{H}]^{+} ; 988.4\left[\mathbf{M}+\mathbf{H}-\mathbf{N H}_{3}\right]^{+} ; 873.4 \mathbf{b}_{8}{ }^{+} ; 855.4 \mathbf{b}_{8}{ }^{+}-\mathbf{H}_{2} \mathbf{O} \\
776.4 \mathbf{b}_{7}^{+} ; 758.3 \mathbf{b}_{7}^{+}-\mathbf{H}_{2} \mathbf{O} ; 748.5 \mathbf{a}_{7}^{+} ; 731.6 \mathbf{b}_{7}^{+}-\mathbf{H}_{2} \mathbf{O}-\mathbf{N H}_{3} \\
566.5 \mathbf{b}_{5}^{+} ; 369.2 \mathbf{x}_{3}^{+}\end{array}$ \\
\hline & MPIQA & Goat $\beta$-CN f183-187 & 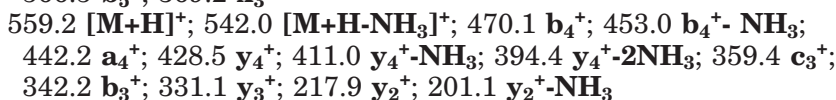 \\
\hline & VFMFPPQSV & Goat $\beta$-CN f155-162 & $\begin{array}{l}904.4[\mathbf{M}+\mathbf{H}]^{+} ; 887.5\left[\mathbf{M}+\mathbf{H}-\mathbf{N H}_{3}\right]^{+} ; 787.3 \mathbf{b}_{7}^{+} ; 759.3 \mathbf{a}_{7}^{+} \\
700.1 \mathbf{b}_{6}^{+} ; 674 \mathbf{y}_{6}^{+} ; 527.3 \mathbf{y}_{5}^{+} ; 430.0 \mathbf{y}_{4}^{+}\end{array}$ \\
\hline & VVAPFPE & Goat $\alpha_{\mathrm{S} 1}-\mathrm{CN}$ f24-30 & $\begin{array}{l}758.4[\mathbf{M}+\mathbf{H}]^{+} ; 740.5\left[\mathbf{M}+\mathbf{H}-\mathbf{H}_{2} \mathbf{O}\right]^{+} ; 586.3 \mathbf{x}_{5}^{+} ; 560.2 \mathbf{y}_{5}^{+} ; \\
514.4 \mathbf{b}_{5}^{+} ; 489.1 \mathbf{y}_{4}^{+} ; 486.1 \mathbf{a}_{5}^{+} ; 471.1 \mathbf{y}_{4}^{+}-\mathbf{H}_{2} \mathbf{O} ; 392.4 \mathbf{y}_{\mathbf{3}}^{+} ; \\
245.1 \mathbf{y}_{2}^{+}\end{array}$ \\
\hline
\end{tabular}

${ }^{1}$ Ions of MS/MS spectra assigned of these peptide fragments were similar to those reported previously.

culture broths, and incubated at 30 or $37^{\circ} \mathrm{C}$ for $24 \mathrm{~h}$. No growth was observed, thus supposing a potential bactericidal mode of action of the peptides contained in the cheese water-soluble extracts.

\section{DISCUSSION}

Milk and dairy products provide a rich source of valuable proteins, minerals, and vitamins. The nutritional significance of proteins includes macronutrient as well as physiological and functional aspects. Besides bioactive proteins, dairy products may also provide peptides. These are formed by enzymatic hydrolysis of intact proteins, which themselves are not necessarily bioactive (Floris et al., 2003). If enzymatic activation is required to generate bioactive peptides, proteolysis has to be considered the major event of cheese ripening. This study reports the presence of potential antibacterial peptides in several Italian cheese varieties.

Parmigiano Reggiano, Fossa, and Gorgonzola watersoluble extracts did not show the presence of antibacte- rial peptides. These cheeses were characterized by the highest ratio of soluble $\mathrm{N} /$ total $\mathrm{N}(\geq 30 \%)$ (Table 1), which reflects a high level of proteolysis. Parmigiano Reggiano is ripened for at least 18 mo, and Fossa is subjected to a very intense proteolysis during ripening in a pit (Gobbetti et al., 1999). Penicillium roqueforti, in addition to thermophilic lactic acid bacteria, markedly contributes to ripening of Gorgonzola cheese. Meisel et al. (1997) reported that proteolysis during cheese ripening increased ACE-inhibitory activity but only to a certain level, after which the ACE-inhibition index decreased. The ACE-inhibitory activity in mediumaged Gouda was about double that of the long-ripened Gouda. An $\alpha_{\mathrm{s} 1}-\mathrm{CN}$-derived antihypertensive peptide, isolated from 6 mo-ripened Parmigiano Reggiano cheese (Addeo et al., 1992), was not detectable after 15 mo of ripening. These results may indicate that bioactive peptides, in our case antibacterial peptides, once liberated by proteolytic enzymes during cheese ripening are degraded further to inactive fragments because of extensive proteolysis (Meisel et al., 1997).

Table 3. Antibacterial activity (minimal inhibitory concentration, $\mu \mathrm{g} / \mathrm{mL})^{1}$ of several fractions isolated from the water-soluble extracts of Italian cheeses.

\begin{tabular}{|c|c|c|c|c|c|}
\hline Indicator species & $\begin{array}{l}\text { Pecorino } \\
\text { Romano, } \\
\text { fraction } 21\end{array}$ & $\begin{array}{l}\text { Canestrato } \\
\text { Pugliese, } \\
\text { fraction } 22\end{array}$ & $\begin{array}{l}\text { Caciocavallo, } \\
\text { fraction } 3\end{array}$ & $\begin{array}{l}\text { Crescenza, } \\
\text { fraction } 22\end{array}$ & $\begin{array}{l}\text { Caprino del } \\
\text { Piemonte, } \\
\text { fraction } 19\end{array}$ \\
\hline & & & $-\mu \mathrm{g} / \mathrm{mL}$ & & \\
\hline Lactobacillus sakei A15 & 25 & 50 & 200 & 70 & 30 \\
\hline Lactobacillus helveticus PR4 & 110 & 160 & - & 250 & 90 \\
\hline Lactococcus lactis spp. cremoris WG2 & 60 & 110 & - & 150 & 50 \\
\hline Escherichia coli $\mathrm{K} 12$ & 25 & 50 & 400 & 150 & 30 \\
\hline Bacillus megaterium F6 & 60 & 50 & 400 & 70 & 25 \\
\hline Listeria innocua DSM 20649 & 70 & 50 & - & 150 & 50 \\
\hline Staphylococcus aureus ATCC25923 & 70 & 200 & - & 170 & 60 \\
\hline Salmonella spp. & 20 & 130 & - & 80 & 25 \\
\hline Yersinia enterocolitica $\mathrm{X} 8$ & 75 & 110 & - & 85 & 60 \\
\hline
\end{tabular}

${ }^{1} \mathrm{MIC}$ was defined as the minimum concentration of peptide fraction required to inhibit bacterial growth measuring by monitoring the absorbance at $620 \mathrm{~nm}$. 
Pecorino Romano, Canestrato Pugliese, Crescenza, and Caprino del Piemonte contained antimicrobial fractions that eluted in the same range of the acetonitrile gradient. The peptides identified in the different fractions showed a high degree of homology. The above cheeses differed for the type of cheese milk and for several technological traits (e.g., type of starters) but were commonly characterized by an $\mathrm{N}_{\text {soluble }} / \mathrm{N}_{\text {total }}$ ratio ranging from 12 to $24 \%$. In addition, the chymosin used in the different preparations (lamb paste, calf powder or liquid) could represent the main agent for proteolysis due to the lack of cooking the curd or the very mild heating ( 45 to $46^{\circ} \mathrm{C}$ for Pecorino Romano cheese) (Table 1). Fraction 21 of Pecorino Romano cheese contained the peptides RFVVAPFPE and VVAPFPEV corresponding to sheep $\alpha_{\mathrm{S} 1}-\mathrm{CN}$ f22-30 and f24-31, respectively (Table 2). The sequences FVAPFPEVFG ( cow $\alpha_{\mathrm{S1}^{-}}$ CN f24-33), FVAPFPEVF (cow $\alpha_{\mathrm{S} 1}-\mathrm{CN}$ f24-32), and VVAPFPE (goat $\alpha_{\mathrm{S} 1}-\mathrm{CN}$ f24-30) were also identified in fractions 22 and 23 of Canestrato Pugliese, 22 and 23 of Crescenza, and 19 of Caprino del Piemonte, respectively. Caseins are the products of 4 genes in mammals that are proposed to have a common precursor. Although considerable variation is found in the relative proportions of the particular caseins across species, it is not surprising to find a certain degree of homology for specific sequences among the different milk species (Ginger and Grigor, 1999). Except for the last C-terminal Lys residue, the sequence FVAPFPEVFG corresponds to the well-known $\alpha_{\mathrm{S1}}$-casokinin ( 34) generated through trypsin hydrolysis (Meisel and Bockelmann, 1999). $\alpha_{\mathrm{S} 1}$-Casokinin is reported in the literature as an example of multifunctional bioactive peptides with mainly ACE-inhibitory activity. Interestingly, several milk-derived peptides reveal multifunctional properties (specific peptide sequences having 2 or more different physiological activities). Some regions in the primary structure of caseins contain overlapping peptide sequences that exert different activities. These regions have been considered "strategic zones" that are partially protected from further breakdown (Fiat et al., 1993). Fraction 21 of Pecorino Romano cheese also contained the peptides GLSPEVLNENLL (sheep $\alpha_{\mathrm{S} 1} \mathrm{CN}$ f10-21) and VMFPPQSVL ( $\beta$-CN f155-163) (Table 2). Except for the substitution of Gln with Ser, the fragment GLSPEVLNENLL is contained in the sequence of isracidin $\left(\alpha_{\mathrm{s} 1}-\mathrm{CN}\right.$ f1-23) from cow's milk (Hill et al., 1974). This antibacterial peptide corresponds to the primary site of cleavage of $\alpha_{\mathrm{s} 1}$-CN by chymosin during primary cheese proteolysis. Further breakdown could be expected during late Pecorino Romano ripening. Isracidin was found to inhibit in vitro growth of lactobacilli and other gram-positive bacteria but only at relatively high concentrations ( 0.1 to $1 \mathrm{mg} / \mathrm{mL}$ ). Neverthe- less, isracidin exerts a strong protective effect against Staph. aureus, Streptococcus pyogenes, and L. monocytogenes in vivo when administered at doses as low as $10 \mu \mathrm{g}$ per mouse before bacterial challenge. Under our conditions, fraction 21 of Pecorino Romano cheese, which also contained the sequence GLSPEVLNENLL, had inhibitory activity toward several potentially pathogenic bacteria of clinical interest, including Staph. aureus and L. innocua. The sequence VMFPPQSVL ( $\beta$-CN f155-163) was also identified in the Caprino del Piemonte cheese as the goat $\beta$-CN f155162 , which did not contain Leu as the $\mathrm{N}$-terminal residue.

Canestrato Pugliese was made of a mixture of cows' and sheep's milk (Table 1). The 3 antibacterial fractions (21, 22, and 23) of Canestrato Pugliese cheese had in common the fragments MAIPPKKNQD (cow $\kappa$-CN f106-115), TVQVTSTAV ( $\kappa$-CN f161-169), and MPIQAF (sheep $\beta$-CN f183-188). Fraction 22 also contained $\alpha_{\mathrm{S} 1}-\mathrm{CN}$ f24-33, whereas fraction 23 had $\alpha_{\mathrm{S} 1}-\mathrm{CN}$ f24-33 and $\alpha_{\mathrm{S} 1}-\mathrm{CN}$ f33-43 (Table 2). The inhibitory spectrum of fractions 22 and 23 was wider than fraction 21 . The peptide MAIPPKKNQD corresponds entirely to the Nterminal fragment of kappacin ( $\kappa$-CN f106-169) (Malkoski et al., 2001) and, except for the C-terminal residue, to casoplatelin (Chabance et al., 1998). Kappacin has been identified as a potent antibacterial peptide that exhibited inhibitory activity toward gram-positive (Streptococcus mutans) and gram-negative (Pseudomonas gingivalis and E. coli) bacteria. Casoplatelin is another example of a multifunctional peptide, mainly antithrombotic with inhibition of platelet aggregation, which has been produced from milk by trypsin hydrolysis. Peptide MAIPPKKNQD was also identified in fraction 22 of Crescenza cheese. Interestingly, the peptide TVQVTSTAV, found in the 3 fractions of Canestrato Pugliese cheese, corresponds entirely to the C-terminal part of kappacin (Malkoski et al., 2001). The sequence MPIQAF was also identified in fraction 22 of Crescenza (as a part of cow $\beta$-CN f175-182) and in fraction 19 of Caprino del Piemonte (goat $\beta$-CN f183-187) cheeses.

Fraction 22 of Crescenza cheese contained the mixture of cow $\kappa$-CN f106-115, YQEPVLGPVRGPFPIIV ( $\beta$-CN f183-199), $\beta$-CN f175-182, and $\alpha_{\mathrm{S} 1}-\mathrm{CN}$ f24-33. Fraction 23 only contained $\alpha_{\mathrm{S} 1}-\mathrm{CN}$ f24-33. With differences for several amino acid residues, the peptide $\beta$ CN f183-199 originated from the same region of the antibacterial peptide $\beta$-CN f184-210 synthesized by hydrolysis of human sodium caseinate with the partially purified proteinase of $L$. helveticus (Minervini et al., 2003).

Fraction 19 of Caprino del Piemonte contained the mixture of YPFTGPIPN (goat $\beta$-CN f60-68), $\beta$-CN f183-187, $\beta$-CN f155-162, and $\alpha_{\mathrm{S} 1-\mathrm{CN}}$ f24-30. The pep- 
tide YPFTGPIPN has an elevated homology with $\beta$ casomorphin-11 (YPFPGPIPNSL), a multifunctional, mainly opioid, peptide isolated from intestinal chyme (Meisel and Bockelmann, 1999).

Differently from the other varieties, Caciocavallo and Mozzarella, the only pasta filata cheeses, showed antibacterial activity in a fraction collected in the first part of the chromatogram (fraction 3). Caciocavallo cheese contained RPKHPIK (cow $\alpha_{\mathrm{S} 1} \mathrm{CN}$ f1-7) and GLPQE $\left(\alpha_{\mathrm{S} 1}-\mathrm{CN}\right.$ f10-14), which are the $\mathrm{N}$-terminal and intermediate fragments of isracidin $\left(\alpha_{\mathrm{S} 1}-\mathrm{CN}\right.$ f1-23) (Hill et al., 1974), respectively.

A bactericidal mode of action potentially characterized the mixture of peptides contained in the cheese water-soluble extracts; after antibacterial assay by broth microdilution technique, no growth of indicator strains was found by plating or by resuspending cells in fresh culture broths under optimal conditions. Although containing a mixture of peptides, the MIC of fractions isolated from some Italian cheese varieties were found to be in the range of 25 to $70 \mu \mathrm{g} / \mathrm{mL}$, which compares well with the concentrations ( 4 to $10 \mu \mathrm{g} / \mathrm{mL}$ ) of some potent antimicrobial peptides (Hancock and Leher, 1998). Based on theoretical calculations, Meisel (1998) estimated that 10 to $60 \mathrm{mg}$ of bioactive peptides could be generated from the hydrolysis of $1 \mathrm{~g}$ of each of the major casein and whey protein components. Therefore, cheeses characterized by an $\mathrm{N}_{\text {soluble }} / \mathrm{N}_{\text {total }}$ ratio of 12 to $24 \%$ could contain noticeable amounts of bioactive peptides.

Antibacterial peptides from food protein deserve attention due to their mechanism of activity, which makes microbial resistance improbable (Floris et al., 2003), and for increasing the functional values of foods. This study demonstrates several key points. First, several Italian cheeses contain peptides with high levels of homology with well-known antimicrobial or multifunctional peptides. Second, long ripening and intense proteolysis may cause the breakdown of biologically active sequences. Third, as previously shown using sodium caseinate from several milk species (Minervini et al., 2003), cheeses manufactured with different types of cheese milk (cow, sheep, and goat) have the potential to generate similar peptides with antimicrobial activity. Finally, chymosin may be one of the major agents responsible for the generation of antimicrobial fragments during cheese ripening (not excluding the potential role of lactic acid bacteria proteases).

\section{REFERENCES}

Addeo, F., L. Chianese, A. Salzano, R. Sacchi, U. Cappuccio, P. Ferranti, and A. Malorni. 1992. Characterization of the $12 \%$ trichloroacetic acid-insoluble oligopeptides of Parmigiano-Reggiano cheese. J. Dairy Res. 59:401-411.
Bechinger, B. 1997. Structure and functions of channel-forming peptides: Magainins, cecropins, melittin and alamethicin. J. Membr. Biol. 156:197-211.

Bellamy, W., M. Takase, K. Yamauchi, H. Wakabayashi, K. Kawase, and M. Tomita. 1992. Identification of the bactericidal domain of lactoferrin. Biochim. Biophys. Acta 1121:130-136.

Chabance, B., P. Marteau, J. C. Rambaud, D. Migliore-Samour, M. Boynard, P. Perrotin, R. Guillet, P. Jollès, and A. M. Fiat. 1998. Casein peptide release and passage to the blood in humans during digestion of milk or yogurt. Biochimie 80:155-165.

Church, F. C., H. E. Swaisgood, D. H. Porter, and G. L. Catignani. 1983. Spectrophotometric assay using o-phthaldialdehyde for determination of proteolysis in milk and isolated milk proteins $\mathrm{J}$. Dairy Sci. 66:1219-1227.

Clare, D. A., and H. E. Swaisgood. 2000. Bioactive milk peptides: A prospectus. J. Dairy Sci. 83:1187-1195.

Epand, R. C., and H. J. Vogel. 1999. Diversity of antimicrobial peptides and their mechanisms of action. Biochim. Biophys. Acta 1462:11-28.

Fiat, A. M., D. Migliore-Samour, P. Jollès, L. Drouet, C. B. D. Sollier, and J. Caen. 1993. Biologically active peptides from milk proteins with emphasis on two examples concerning antithrombotic and immunomodulating activities. J. Dairy Sci. 76:301-310.

Floris, R., I. Recio, B. Berkhout, and S. Visser. 2003. Antibacterial and antiviral effects of milk proteins and derivatives thereof. Curr. Pharm. Des. 9:1257-1273.

Ginger, M. R., and M. R. Grigor. 1999. Comparative aspects of milk caseins. Comp. Biochem. Physiol. 124:133-145.

Gobbetti, M., B. Folkertsma, P. F. Fox, A. Corsetti, E. Smacchi, M. De Angelis, J. Rossi, K. Kilcawley, and M. Cortini. 1999. Microbiology and biochemistry of Fossa (pit) cheese. Int. Dairy J. 9:763-773.

Gobbetti, M., F. Minervini, and C. G. Rizzello. 2004. Angiotensin Iconverting-enzyme-inhibitory and antimicrobial bioactive peptides. Int. J. Dairy Technol. 57:173-188.

Gobbetti, M., L. Stepaniak, M. De Angelis, A. Corsetti, and R. Di Cagno. 2002. Latent bioactive peptides in milk proteins: Proteolytic activation and significance in dairy processing. Crit. Rev. Food Sci. Nutr. 42:223-239.

Gomez-Ruiz, J. A., M. Ramos, and I. Recio. 2002. Angiotensin converting enzyme inhibitory peptides in Manchego cheeses manufactured with different starter cultures. Int. Dairy J. 12:697-706.

Haileselassie, S., B. H. Lee, and B. F. Gibbs. 1999. Purification and identification of potentially bioactive peptides from enzyme-modified cheese. J. Dairy Sci. 82:1612-1627.

Hancock, R. E. W., and L. Leher. 1998. Cationic peptides: A new source of antibiotics. Trends Biotechnol. 16:82-88.

Hill, R. D., E. Lahov, and D. Givol. 1974. A rennin-sensitive bond in alpha and beta casein. J. Dairy Res. 41:147-153.

International Dairy Federation. 1989. Determination of $\mathrm{pH}$. Standard 115A, International Dairy Federation, Brussels, Belgium.

Jones, F. S., and H. S. Simms. 1930. The bacterial growth inhibitor (lactenin) of milk. J. Exp. Med. 51:327-339.

Korhonen, H., and A. Pihlanto. 2003. Bioactive peptides: Novel applications for milk proteins. Appl. Biotechnol. Food Sci. Policy $1: 133-144$.

Kuchroo, C. N., and P. F. Fox. 1982. Soluble nitrogen in Cheddar cheese: Comparison of extraction procedures. Milchwissenschaft 37:331.

Lahov, E., D. Edelsten, M. T. Sode-Morgensen, and E. Sofer. 1971. Properties of basic glycopeptides released from cow milk protein by heat. Milchwissenschaft 26:489-495.

Liepke, C., H. D. Zucht, W. G. Forsmann, and L. Standker. 2001. Purification of novel peptide antibiotics from human milk. J. Chromatogr. 752:369-377.

Malkoski, M., S. G. Dashper, N. M. O’Brien-Simpson, G. H. Talbo, M. Macris, and K. J. Cross. 2001. Kappacin, a novel antibacterial peptide from bovine milk. Antimicrob. Agents Chemother. 45:2309-2315.

Meisel, H. 1998. Overview on milk protein-derived peptides. Int. Dairy J. 8:363-373.

Meisel, H. 2001. Bioactive peptides from milk proteins: A perspective for consumers and producers. Aust. J. Dairy Technol. 56:83-91. 
Meisel, H., and W. Bockelmann. 1999. Bioactive peptides encrypted in milk proteins: Proteolytic activation and thropo-functional properties. Antonie Van Leeuwenhoek 76:207-215.

Meisel, H., A. Goepfert, and S. Günther. 1997. ACE inhibitory activities in milk products. Milchwissenschaft 52:307-311.

Minervini, F., F. Algaron, C. G. Rizzello, P. F. Fox, V. Monnet, and M. Gobbetti. 2003. Angiotensin I-converting-enzyme-inhibitory and antibacterial peptides from Lactobacillus helveticus PR4 proteinase-hydrolyzed caseins of milk from six species. Appl. Environ. Microbiol. 69:5297-5305.

Pellegrini, A., C. Dettling, U. Thomas, and P. Hunziker. 2001. Isolation and characterization of four domains in the bovine $\beta$-lactoglobulin. Biochim. Biophys. Acta 1526:131-140.

Pellegrino, L., G. Battelli, P. Resmini, P. Ferranti, F. Barone, and F. Addeo. 1997. Alkaline phosphatase inactivation during Grana Padano cheese-making and related effects on cheese characterization and ripening. Lait 77:217-220.
Recio, I., and S. Visser. 1999. Identification of two distinct antibacterial domains within the sequenze of bovine $\alpha$ s2-casein. Biochim. Biophys. Acta 1428:314-326.

Roudot-Algaron, F., D. Le Bars, L. Kerhoas, J. Einhorn, and J. C. Grippon. 1994. Phosphopeptides from Comté cheese, nature and origin. J. Food Sci. 59:544-547.

Ryhänen, E. L., A. Philanto-Leppala, and E. Pahkala. 2001. A new type of ripened, low-fat cheese with bioactive properties. Int. Dairy J. 11:441-447.

Schillinger, U., and F. K. Lucke. 1989. Antibacterial activity of Lactobacillus sakei isolated from meat. Appl. Environ. Microbiol. 55:1901-1906.

Smacchi, E., and M. Gobbetti. 2000. Bioactive peptides in dairy products: Synthesis and interaction with proteolytic enzymes. Food Microbiol. 17:129-141.

Zucht, H. D., M. Raida, K. Adermann, H. J. Mägert, and W. G. Forssmann. 1995. Casocidin-I: A casein- $\alpha_{\mathrm{S} 2}$ derived peptide exhibits antibacterial activity. FEBS Lett. 372:185-188. 